Univerzitet u Beogradu
Poljoprivredni fakultet
Institut za poljoprivrednu tehniku
Naučni časopis
POLJOPRIVREDNA TEHNIKA
Godina XLIV
Broj 3, 2019.
Strane: $69-77$

\title{
EFFECT OF SOIL TYPE ON POWER AND ENERGY REQUIREMENTS OF SOME SELECTED AGRICULTURAL FIELD MACHINERY IN SOUTH - EAST NIGERIA
}

\author{
Okechukwu Oduma $^{1 *}$, Sylvester I. Oluka ${ }^{2}$ \\ ${ }^{l}$ Department of Agricultural \& Bioresources Engineering, \\ Michael Okpara University of Agriculture, \\ Umudike, Umuahia, Abia State, Nigeria \\ ${ }^{2}$ Department of Agricultural \& Bioresources Engineering \\ Enugu State University of Science and Technology, \\ Enugu State, Nigeria
}

\begin{abstract}
The effect of soil type on power and energy requirements of some selected agricultural field machinery (plough, harrow, ridger, rotovator and planter) in south east Nigeria were studied to enable farmers and users of the equipment select and match appropriately the size of implements and speed of operation to machine (tractor) size to improve the field capacitive performance of the machines based on soil types (clay loam, loamy - sandy, and sandy - clay soil) in the study area. Results showed that plough recorded the highest fuel (energy) consumption rate of $21.60 \mathrm{l} / \mathrm{ha}$ to24.67 l/ha, followed by harrow with fuel consumption rate of 17.21 to $21.66 \mathrm{l} / \mathrm{ha}$, rotovator (15.22 to $19.72 \mathrm{l} / \mathrm{ha}$ ) and least was planter with fuel consumption rate range from 14.42 to 15.62 1/ha. The highest fuel consumption was recorded on clay-loam soil, followed by sandyclay and least was on loamy-sandy soil. The plough also had the highest draft force (10.8 $\mathrm{kN} / \mathrm{m}$ ), followed by the harrow and ridger with equal draft force of $10.5 \mathrm{kN} / \mathrm{m}$, planter $(8.4 \mathrm{kN} / \mathrm{m})$ and the least was the rotovator with draft force of $5.1 \mathrm{kN} / \mathrm{m}$. Furthermore, the plough gave the highest wheel slippage $(15.7 \%)$ followed by harrow $(13.3 \%)$, rotovator and planter with equal value of wheel slippage $(12.8 \%)$ and least was ridger with wheel slippage of $12.4 \%$. Sandy-clay soil recorded the highest tyre slippage for all the implements, followed by loamy-sandy and the least tyre slippage was recorded on clayloam soil. However, all the implements in different soils corded average wheel slippage below the top limit of wheel slippage ( $20 \%$ ), showing that the soils were trafficability.
\end{abstract}

Key words: Capacitive performance, energy, famers, field machinery, power, soil type

\footnotetext{
* Correspond Author. E-mail address: odumaoke@ gmail.com
} 


\section{INTRODUCTION}

Energy is significant indicator in farm operations. According to Updhyaya et al [1] it plays important role in different land tillage operations, seed planting operation, application of fertilizers, pest/weed controls harvesting of crops etc. Therefore, fuel cost of tillage and/or agricultural productivities should be effortlessly kept at a reduced level to ensure that no amount of operation will lead to high operation cost per hour or keep the cost at a prohibitive level. Thus, machinery operation should be simple and cheap, consistent and low in fuel consumption [2]. Bukhari and Baloch [3], observed that operation speed, implement effective working width and cutting depth, soil type/conditions and operator's skill of operation influence fuel (energy) consumption rate. It therefore, means that size of implement and speed of operation should be matched to machine size to improve the field capacitive performance of the machine [4].

The major operations that are necessary in agricultural operation are mechanical land clearing, land preparation, seed planting, weeding, fertilizer application and harvesting. These are achieved by effective utilization and management of tractors and their coupled implements. Efficient machinery utilization and/ or management needs accurate performance, power and energy requirement data on the capabilities of the individual machines to achieve a given work schedule and to obtain a balanced mechanization system by matching the performance of different farm equipment. The variation in agro-ecological soil condition requires the knowledge of the energy and power requirements of the coupled implements. Producers of these machines do not make the data available for the farmers in Nigeria; it should have been a better guide in the selection of the implements based on the soil differences applicable in various agricultural regions in Nigeria [5].

Today's competitive agricultural market demands better utilization/ management of resources and minimization of operating costs so as to optimize production and increase profits. One of the major costs of any agricultural production system is machinery cost. Increasing the performance efficiency of farm machinery may lead to a serious cost reduction. Farmers like other business ventures strive to cover up their expenditures in addition to the cost of the machinery and this is why Yohanna and Ifem [6] noted that an intelligent and well experienced farmer tries to make proper use of farm inputs (seeds, fertilizers, herbicides or insecticides, irrigation water and farm equipment) so as to reduce cost. In Nigeria farm mechanization technology has continually been importoriented. Agricultural machines and equipment are imported from different countries into Nigeria to aid the different farm mechanization decisions of the government [7]. Presently, the cost of importation of agricultural machinery has been sky rocketed due to the devaluation of the local currency, and to operate within such a bad economic condition, machinery managers, owners and/or users must be careful in selecting and purchasing new machinery. It is therefore necessary that the users should know how a machine performs a given task and the ease and/or rate with which it does the work without failure or breakdown and at minimal wastage of energy.

Huge amount of money is invested by farmers annually in purchasing/hiring, operation, maintenance and management of agricultural field machinery. Most of these machines breakdown/fail unnecessarily during operation, in addition to high energy and power losses incurred in operation due to improper selection of machinery that suit the soil condition and/or mismatching of the implements with the prime mover. 
Knowledge of the energy and power unit of the machines will effortlessly ameliorate the plight of farmers, and help them to improve and optimize their production when they make better selection of machines that will match their soil type/conditions.

The aim of this study is to determine the energy and power requirements of some selected agricultural field machinery in South-East Nigeria. This is to obtain data on their fuel consumption rate and power units needed for their operation based on soil type which will guide farmers in machine selection to reduce cost, energy loss, and failure/breakdown and increase their production.

\section{MATERIAL AND METHODS}

\section{Description of Experimental Site}

The experiment was conducted at five different locations, where the dominant soils (clay-loam, loamy-sandy and sandy- clay soil) in the study area are located, These locations include: demonstration farm of veterinary school, Ezzangbo, OhaukWu L. G. A. Ebonyi State; demonstration farm of department of Agricultural and Bio-Resources Engineering, college of Engineering and Engineering Technology, Michael, Okpara University of Agriculture, Umudike, Abia State; demonstration farm of Department of Agricultural and Bio-Resources Engineering, faculty of Engineering, Nnamdi Azikiwe University, Anambra State; demonstration farm of department of Agriculture, Federal College of Education Ehamufu, Enugu State and in Achara Ubo Ubowalla Emekuku, Oweri North L.G.A., Imo state. The soil in the first and second locations is clay-loam, in the third location the soil is loamy-sandy while in the fourth and fifth locations the soil was sandy- clay.

The tests was conducted in May, through June, July, August, September and October, which coincide with planting season of the year; and which also offer the tractor and the coupled implements an exposure to wide range of soil conditions.

Prior to the field operation test, the soil physical properties such as moisture content, bulk density, porosity and texture which influence energy and power consumption rate of the implements were determined in the various sites used for the study.

\section{Description of Machine Used for the Test}

A Massey Ferguson tractor of model MF430E and capacity $55.2 \mathrm{~kW}$, with 3-point hitch systems and age of 5months from date of first hand purchase was hired and used for the study. The hitched implements that were studied include ploughs, harrows, rotovators, ridgers, and planters.

\section{Field Operation Test}

The field operations such as ploughing, harrowing, ridging, pulverization and sowing were generally performed longitudinally with the implement full width at selected forward speeds and cutting depth, the distance travelled and the corresponding time taken to complete the working distance were noted; and the energy and power requirements of the various implements were determined as stated below. 


\section{Measurement of Fuel Consumption}

A graduated cylindrical container was used to measure the amount of fuel required to refill the fuel tank of the tractor immediately after each operation as used by Udo and Akubuo [2]. This measurement provided the quantity of fuel consumed during each experiment. The fuel consumption rates was calculated in liter/ha and liter/hr as suggested by Alnahas [8].

Rate of consumption $(1 / \mathrm{ha})=\frac{\text { Reading of } \text { cylinder, } \text {, itres }}{\text { Area of land covered, } \text {, acters }}$

Rate of consumption $(1 / \mathrm{h})=\frac{\text { Reading of cylinder, litres }}{\text { Time taken to coverthe land area,hours }}$

\section{Determination of Power requirement of the implements}

\section{Draft Force}

Draft can be evaluated due to drawbar power (it is the power, in relation to pull-type or mounted implements, actually required to pull or move the implement at uniform speed) by the following equation [9]:-

Where:

$$
D=\frac{C \times D B P}{S}
$$

$D=$ draft, $\mathrm{kN}$

$C=$ constant, 3.6

$D B P=$ drawbar power, $[\mathrm{kW}]$,

$S=$ travel speed, $\mathrm{km}^{-1}$.

\section{Drawbar Power}

This is the power transferred through the drive wheels or tracks to move the tractor and implement It was evaluated from equation 2 according to Hunt [10].

Drawbar power $=\frac{\text { total draft },(k N) \times \text { speed } \mathrm{km}^{-1}}{36}$

\section{Slippage (Travel reduction)}

According to Ani et al. [11] the tyre slippage is estimated from the following formula

Where is:

$$
\text { Tyre slip }=\frac{V a}{V t}
$$

$\mathrm{Va}=$ speed of tractor when implement is engage (under load), $\mathrm{km}$

$\mathrm{Vt}=$ speed of tractor when implement is disengaged (no load), $\mathrm{km}$ 


\section{RESULT AND DISCUSION}

Table 1. Effect of soil type on Fuel consumption rate at different soil type/ conditions

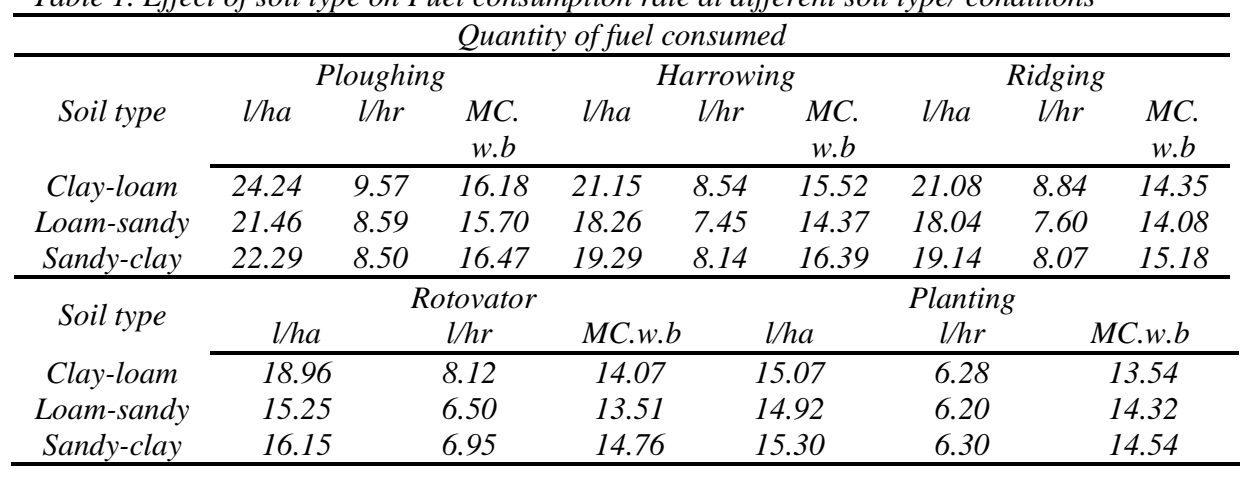

Results of Table 1., indicates that ploughing recorded the highest average fuel consumption rate 24.24 1/hain clay-loam soil, 22.29 1/ha in sandy-clay, and 21.29 1/ha in loamy-sandy soil. This is closely followed by harrowing operation with fuel consumption rate of $21.15 \mathrm{l} / \mathrm{ha}$ in clay-loam, $19.29 \mathrm{l} / \mathrm{ha}$ in sandy-clay and 18.26 1/ha in loamy-sandy soil. This is also followed by ridging with average fuel consumption rate of $21.08 \mathrm{l} /$ ha in clay-loam, $19.14 \mathrm{l} / \mathrm{ha}$ in sandy-clay and $18.04 \mathrm{l} / \mathrm{ha}$ in loamy-sandy soil; rotovator with consumption rate of $18.96 \mathrm{l} / \mathrm{ha}$ in clay-loam, $16.15 \mathrm{in}$ sandy-clay and $15.25 \mathrm{l} / \mathrm{ha}$ in loamy-sandy soil. The least average fuel consumption rate was recorded by planter planter with fuel consumption rate of $6.30 \mathrm{l} / \mathrm{ha}, 6.28 \mathrm{l} / \mathrm{ha}$ and $6.20 \mathrm{l} / \mathrm{ha}$ in sandyclay, clay-loam and loamy-sandy soil, respectively. The highest fuel consumption rate of the plough as compared to other implements is due to high tractive and draft force associated with its operation [12].

Table 2: Effect of soil type on implement power requirements under different soil conditions

\begin{tabular}{|c|c|c|c|c|c|c|c|c|c|c|}
\hline \multirow{3}{*}{$\begin{array}{l}\text { Soil type } \\
(\text { M.C.\% w.b) }\end{array}$} & \multicolumn{10}{|c|}{ Implement power requirements } \\
\hline & \multicolumn{2}{|c|}{ Plough } & \multicolumn{2}{|c|}{ Harrow } & \multicolumn{2}{|c|}{ Ridger } & \multicolumn{2}{|c|}{ Rotovator } & \multicolumn{2}{|c|}{ Planter } \\
\hline & $D p$ & $D b$ & $D p$ & $D b$ & $D p$ & $D b$ & $D p$ & $D b$ & $D p$ & $D b$ \\
\hline $\begin{array}{l}\text { Clay-loam } \\
(13.23-17.12\end{array}$ & 10.8 & 18.6 & 10.5 & 17.1 & 10.5 & 18.1 & 5.1 & 8.8 & 8.8 & 13.8 \\
\hline $\begin{array}{l}\text { Loamy-sandy } \\
(13.53-16.20)\end{array}$ & 10.8 & 18.1 & 10.5 & 20.2 & 10.5 & 20.5 & 5.1 & 9.2 & 8.4 & 15.7 \\
\hline $\begin{array}{l}\text { Sandy-clay } \\
16.21-18.63)\end{array}$ & 10.8 & 19.6 & 10.5 & 18.9 & 10.5 & 19.1 & 5.1 & 9.4 & 8.4 & 15.4 \\
\hline Mean & 10.8 & 18.8 & 10.5 & 18.7 & 10.5 & 19.2 & 5.1 & 9.1 & 8.4 & 15.0 \\
\hline
\end{tabular}

Results of Table 2 revealed that each tractor-hitched implement irrespective of soil type and condition had constant draft force. Ploughing recorded the highest constant draft force of $10.8 \mathrm{kN}$; followed by the harrow and ridger with the same draft force of $10.5 \mathrm{kN}$ respectively, planter $(8.4 \mathrm{kN})$ and rotovator has least draft force of $5.1 \mathrm{kN}$. 
In the case of drawbar power, plough recorded average of $18.6 \mathrm{~kW}, 18.1$ and 19.6 $\mathrm{kW}$ power respectively in clay-loam soil, loamy - sandy and sandy- clay soil. In the same other harrow recorded $17.1 \mathrm{~kW}, 20.2 \mathrm{~kW}$ and $18.9 \mathrm{~kW}$ respectively.

The ridger had $18.1 \mathrm{~kW}$ in clay-loam soil, $20.5 \mathrm{~kW}$ power in loamy-sandy soil and 19.1 $\mathrm{kW}$ power in sandy-clay soil while the rotovator had $8.8 \mathrm{~kW}, 9.2 \mathrm{~kW}$ and $9.4 \mathrm{~kW}$ on clay-loam, loamy-sandy and in sandy-clay soil respectively and finally, the planter operated with drawbar power of $13.8 \mathrm{~kW}$ on clay-loam soil, 15.7 and $15.4 \mathrm{~kW}$ on loamysandy and sandy- clay soil respectively. It was generally observed that the plough, harrow and ridger were operated with higher drawbar forces as compared to the rotovator and planter. This may be due to the fact that seeding and rotovator operation do not require much tractive or drawbar power for their operations.

Table 3. Effect of soil type on implement power losses under different soil conditions

\begin{tabular}{lrrrrc}
\hline Soil type & \multicolumn{5}{c}{ Implement power loss } \\
\cline { 2 - 6 } & Plough & Harrow & Ridger & Rotovator & Planter \\
$\begin{array}{l}\text { Clay-loam } \\
(13.23-17.13\end{array}$ & 15.8 & 13.4 & 12.6 & 12.9 & 12.8 \\
$\begin{array}{l}\text { Loamy-sandy } \\
(13.53-16.20)\end{array}$ & 12.8 & 11.7 & 11.1 & 11.6 & 11.4 \\
$\begin{array}{l}\text { Sandy-clay } \\
(16.21-18.63)\end{array}$ & 18.6 & 14.8 & 13.6 & 13.9 & 14.2 \\
Mean & 15.7 & 13.3 & 12.4 & 12.8 & 12.8 \\
\hline
\end{tabular}

Table 3 showed that the plough gave the highest tyre slippage for all the soils. It recorded $15.8 \%$ on clay-loam soil at moisture content range of $13.23-17.12 \%$ (w.b), $12.8 \%$ on loamy-sandy soil (moisture content of $13.53-16.20 \%$ (w.b) and $18.6 \%$ on sandy- clay soil (moisture content of $16.21-18.63 \%$ (w.b). This was followed by the harrow with average tyre slippage of $13.4 \%$ on clay-loam, $11.7 \%$ on loamy-sandy and $14.8 \%$ on sandy-clay soil; the rotovator had average slippage of $12.9 \%$ on clay-loam, $11.6 \%$ on loamy-sandy and $13.9 \%$ 0n sandy-clay soil while the planter recorded 12.8 , 11.4 and $14.2 \%$ on clay-loam, loamy-sandy and sandy-clay soil respectively. The least tyre slippage was recorded by the ridger with average tyre slippage of $12.6 \%$ on clayloam, $11.2 \%$ and $13.6 \%$ on loamy-sandy and sandy- clay respectively.

For all the soils studied, the sandy-clay soil gave the highest tyre slippage for all the implements followed by the clay-loam and the least slippage was encountered on the loamy-sandy soil. This may be as a result of high moisture content observed in sandyclay soil than the other soils making it to be softer with more deforming effect than the other soils. However, results obtained broadly revealed that the average percentage of tyre slippage of all the implements in different soils are below the top limit of wheel slippage of $20 \%$ as recorded by Pensson et al [13] and also as observed by Alnahas [8].

\section{CONCLUSION}

The following conclusion can be made about the study: 
1. Ploughing recorded the highest fuel consumption rate of $21.601 /$ ha to 24.67 1/ha, followed by harrow (17.21 to $21.66 \mathrm{l} / \mathrm{ha}$ ), rotovator (15.22 to $19.72 \mathrm{l} / \mathrm{ha}$ ), and least is the planter with fuel consumption rate range from 14.42 to 15.62 1/ha.

2. The highest fuel consumption was recorded when working on clay-loam soil, followed by sandy-clay and least was on loamy-sandy soil. The variation is due to the high draft force needed to break the high soil compaction in the higher bulk density soil locations than the lower bulk density areas.

3. The plough has the highest draft force $(10.8 \mathrm{kN} / \mathrm{m})$, followed by the harrow and ridger with the same draft force of $10.5 \mathrm{kN} / \mathrm{m}$ ) and the least was the planter with draft force of $5.1 \mathrm{kN} / \mathrm{m}$. The high draft force of the plough is the reason for its high fuel consumption rate.

4. All the implements in different soils recorded average wheel slippage below the top limit of wheel slippage (20\%), showing the soils are trafficability.

5. Sandy-clay soil recorded the highest tyre slippage for all the implements, followed by loamy-sandy and the least tyre slippage was recorded on clay-loam soil.

6. Ploughing gave the highest wheel slippage (15.5\%) followed by harrow (13.1 $\%)$, rotovator $(12.7 \%)$, planter $(12.6 \%)$ and least was ridger $(12.6 \%)$.

\section{RECOMMENDATIONS}

Results of this study form a database that will guide the farmers and agriculturists in selecting farm machineries/implements that will suit the soil conditions in south-east agricultural zone and other agricultural areas with similar soil and ecological conditions.

Differences exist in soil conditions among different agricultural or ecological areas; it is therefore recommended that more studies should be conducted in every agricultural zone to provide data on machine/ implement power and energy requirements based on soil conditions for increased production, minimize production costs, reduce loss/wastage of energy, time and waste of agricultural products.

Finally, this study did not cover all the agricultural field machineries. Researchers are also recommended to make detailed time study in other machineries not covered in this work in other to provide database in their power and energy requirements as to guide farmers here and other agricultural zones in machine/implement selections.

\section{REFERENCES}

[1] Updhyaya, S. K., Williams, T. H.. Kemble, L. J. and Collins, N. E.1984. Energy requirements for chiseling in coastal plain soils. Transactions of the ASAE, 27(6).1643-1649, 7:2.

[2] Udo, D.U.and Akubuo, C.O.2000. Fuel consumption in tillage operations for sandy loam soil. Proceeding of NIAE. pp.74-83.

[3] Bukhari, S. B and Balock, J. M. 1982. Fuel consumption of tillage implements. AMA Japan, 11(3):20-22.

[4] Collins, N. E. Williams, T.H and Kemble L.J.1998 . Energy requirements for grain production system ASAE Pub.,407-411,Asia,Africa and L.America 19(4):9-14. 
[5] Oduma and Oluka 2017. Performance Characteristics of Agricultural Field Machineries in South- East Nigeria. J. of Exp. Research, Vol 5 No 1. pp. 57-71.

[6] Yohanna, J. K. and Ifem, J. L.C. 2000. Performance evaluation of field efficience of farm machinery in Nasarawa and plateau state. Proceeding of NIAE. pp 88-92.

[7] Oluka, S.I.2000. Costs of tractor ownership under different management systems in Nigeria. Nigeria Journal of technology (NIJOTECH), Vol.19. No. 1.pp.15-28.

[8] Alnahas, S.A.M.E. 2003.Tillage Implements Performance and their Effects on Two Types of Soil in Khartoum Area. Thesis submitted to the University of Khartoum in partial fulfillment for the requirement of the Degree of Master of Science in Agricultural Engineering.

[9] Hunt, D. R.1979. Farm power and machinery management .4th edition. Second printing. The Lowa State University Press.

[10] Hunt, D.2013. Farm power and machinery management. Tenth edition. Scientific International congress on agricultural engineering, agriculyural engineering, Dubli. Vol.3., pp. 1703-1709.

[11] Ani, A.O.,Akubuo, C.O. and Odigboh, E.U. 2007.Tractability conditions for disc ploughing on a loamy sand soil in the ilorin agro-ecological zone. Nigeria Journal of technology. Vol.26. No2. pp. 2-8.

[12] Pensson, S. P. E., Klelgaard, W. L. and Wu, Z. 1986. Machine width for time and fuel efficiency. Trans. ASAE.29:1508-1513.

[13] Sale, S. N.,Gwarzor, M. A., Felix, O. G and Idris, S. I. (2013). Performance evaluation of some selected tillage implements. Proc. of NIAE. Vol.34.pp.71-77.

\title{
UTICAJ TIPA ZEMLJIŠTA NA ENERGETSKE ZAHTEVE NEKIH ODABRANIH POLJOPRIVREDNIH MAŠINA U JUGOISTOČNOJ NIGERIJI
}

\author{
OkechukWu Oduma $^{1}$ and Sylvester I. Oluka ${ }^{2}$ \\ ${ }^{I}$ Department of Agricultural \& Bioresources Engineering, \\ Michael Okpara University of Agriculture, \\ Umudike, Umuahia, Abia State, Nigeria \\ ${ }^{2}$ Department of Agricultural \& Bioresources Engineering \\ Enugu State University of Science and Technology, \\ Enugu State, Nigeria
}

Sažetak: Proučavan je uticaj tipa zemljišta na energetske potrebe nekih odabranih poljoprivrednih mašina (plug, drljača, rotofreza i sejalica) u jugoistočnoj Nigeriji, kako bi se poljoprivrednicima i korisnicima opreme omogućilo da odaberu i na odgovarajući način odgovore veličini opreme i brzini rada za poboljšanje kapaciteta polja na mašinama na osnovu tipova zemljišta (glina - ilovača, ilovasto - peskovito i peskovito glinoviti tip) na istraživanom području.

Rezultati pokazuju da je plug imao najveću potrošnju goriva (energije) od 21,60 1/ha do 24,67 1/ha, zatim drljača sa potrošnjom goriva od 17,21 do 21,66 1/ha, rotofreza od 15,22 do 19,72 1/ha. Najmanja potrošnja je bila kod sadilica sa opsegom potrošnje goriva od 14,42 do 15,62 1/ha. 
Najveća potrošnja goriva zabeležena je na glinovito-ilovastim tipovima zemljišta, a zatim na peskovito-glinovitom i najmanje na glinovito-peskovitim tipovima zemljišta.

Plug ima najveću silu vuče od $10.8 \mathrm{kN} / \mathrm{m}$, zatim drljača od $10.5 \mathrm{kN} / \mathrm{m}$, pa sadilica od $8.4 \mathrm{kN} / \mathrm{m}$. Najmanja sila vuče je kod rotofreze od $5.1 \mathrm{kN} / \mathrm{m}$.

Osim toga, plug je prouzrokovao najveće proklizavanje točkova $(15,7 \%)$, zatim drljača $(13,3 \%)$. Rotofreza i sadilica imaju jednake vrednosti proklizavanja točkova (pneumatika) (12,8\%). Najmanja vrednost klizanja točkova je kod kultivatora od 12,4\%.

Peskovito-glinoviti tip zemljišta je imao najveće klizanje pneumatika za sva oruđa, a najmanje klizanje točkova je zabeleženo na zemljištu tipa ilovača.

Međutim, svi priključci na različitim zemljištima imaju prosečno proklizavanje točkova ispod gornje granice klizavanja točkova od $20 \%$, što pokazuje da su ovakva zemljišta pogodna za kretanje mašina.

Ključne reči: Performanse, učinak, energija, farmeri, terenske mašine, snaga, tip zemljišta

Prijavljen:

Submitted:

Ispravljen:

Revised:

Prihvaćen:

Accepted: 